\title{
A new Placoderm fish (Acanthothoraci) from the Early Devonian Jauf Formation (Saudi Arabia)
}

\author{
Sébastien OLIVE \\ Daniel GOUJET \\ Hervé LELIÈVRE \\ UMR 7207, CR2P, CNRS, Muséum national d'Histoire naturelle, \\ case postale 38, 57 rue Cuvier, F-75231 Paris cedex 05 (France) \\ olive@mnhn.fr \\ goujet@mnhn.fr \\ lelievre@mnhn.fr \\ Dominique JANJOU \\ Bureau des Ressources géologiques et minières, \\ 3 avenue Claude Guillemin, F-45060 Orléans (France) \\ d.janjou@brgm.fr
}

KEY WORDS

Acanthothoraci, Placodermi, Arabosteus variabilis n. gen, n. sp., arthrodiran model, endocranium, homology,

skull roof plate,

Saudi Arabia, new genus, new species.
Olive S., Goujet D., Lelièvre H. \& Janjou D. 2011. - A new Placoderm fish (Acanthothoraci) from the Early Devonian Jauf Formation (Saudi Arabia). Geodiversitas 33 (3): 393-409. DOI: $10.5252 / g 2011 \mathrm{n} 3 \mathrm{a} 1$.

\section{ABSTRACT}

An exceptionally well-preserved new acanthothoracid (placoderm fish) presenting complete endocranium and skull roof, from Saudi Arabia (Qasr Limestone Member, Jauf Formation), Early Devonian in age, is described as Arabosteus variabilis n. gen., n. sp. Compared to other Acanthothoraci, the new taxon exhibits a skull roof variable in its dermal plate distribution (e.g., a supernumerary plate: the posterior central plate) and sensory line pattern. Even the different specimens of this taxon show such variability between them. Arabosteus variabilis n. gen., n. sp. enlarges the scope of our knowledge of Acanthothoraci and Placodermi in general. Traditionally, the Arthrodira, one of the historically earliest described groups, provide the standard reference model for the placoderm skull roof pattern. The interpretation of the acanthothoracid skull roof pattern of the Saudi taxon from an arthrodiran model and the establishment of homologies is impossible to resolve unless based on prior assumptions (e.g., hypothesis of fragmentation or fusion for the paranuchal plate complex). The lateral line system of $A$. variabilis n. gen., n. sp. is unstable (e.g., presence or absence of the postmarginal sensory line canal) making it ambiguous to define bone homology and terminology. Consequently spatial distribution of skull roof plates has been retained for such a task with a minimal reference to the instable features of the sensory line groove distribution. 


\author{
MOTS CLÉS \\ Acanthothoraci, \\ Placodermi, \\ Arabosteus variabilis \\ n. gen., n. sp., \\ modèle arthrodire, \\ endocrâne, \\ homologie, \\ plaque du toit crânien, \\ Arabie Saoudite, \\ genre nouveau, \\ espèce nouvelle.
}

\section{RÉSUMÉ}

Un nouveau placoderme (Acanthothoraci) du Dévonien inférieur de la Formation de Jauf (Arabie Saoudite).

Un nouvel Acanthothoraci (Placodermi) du Dévonien inférieur d'Arabie Saoudite (Qasr Limestone Member, Jauf Formation), exceptionnellement bien conservé, présentant un endocrâne et un toit crânien complets, est décrit en tant qu'Arabosteus variabilis $\mathrm{n}$. gen., n. sp. Ce nouveau taxon présente une variabilité importante au niveau de l'agencement des plaques dermiques (e.g., une plaque surnuméraire: la plaque centrale postérieure) et de la distribution des canaux sensoriels de son toit crânien, non seulement vis-à-vis des autres Acanthothoraci mais également entre les différents individus représentés au sein de ce taxon. Il permet d'élargir la connaissance des caractères anatomiques des Acanthothoraci et des placodermes en général. Classiquement les arthrodires, l'un des plus anciens clades de placodermes décrits, ont servi de référence dans le débat sur l'établissement d'homologies concernant les plaques du toit crânien des autres groupes. L'interprétation de la distribution des plaques crâniennes d'Arabosteus variabilis $\mathrm{n}$. gen., n. sp. à partir du modèle arthrodire, et l'établissement d'homologies, se révèlent impossibles, à moins de se baser sur des hypothèses préalables (e.g., processus de fragmentation ou de fusion pour le complexe des plaques paranuchales). Le système des lignes sensorielles $\mathrm{d}$ 'A. variabilis $\mathrm{n}$. gen., n. sp. est instable (e.g., présence ou absence du canal postmarginal) et donc ambigu pour décider d'une terminologie et de l'établissement d'homologies des plaques du toit crânien. Ainsi, une terminologie topographique a été retenue pour une telle tâche en minimisant les références aux caractères instables du système des lignes sensorielles.

\section{INTRODUCTION}

The Acanthothoraci occupy a special position among placoderms (Goujet \& Young 1995). They show a mixture of plesiomorphic characteristics, placing them as a basal branch of the placoderm tree, and remarkable apomorphic characteristics, which make them a group very different from the other placoderms. Moreover, they are among the oldest representatives of the group known since the Lochkovian (Orvig 1975; Smith 1980).

The new material studied here was collected in the Al Qalibah area, Saudi Arabia, by a team including Hervé Lelièvre and Philippe Janvier in 1992. It comes from the Qasr Limestone Member at the base of the Early Devonian Jauf Formation (Lelièvre et al. 1999). The material is represented by numerous isolated elements (Burrow et al. 2006) but the most representative ones are acanthothoracid skulls.

To date, very few acanthothoracid skulls have been published (Gross 1958; Mark-Kurik 1973; Orvig 1975; Denison 1978; Young 1980) and they all present a high degree of variability. Therefore establishing homologies with other placoderm dermal skull roof plates is quite uncertain. This question is central to the study of the material from Saudi Arabia presented here in order to define the homologies necessary in establishing relationships.

\section{MATERIAL AND METHODS}

On the Arabian plate, the Devonian crops out in the central region (Forey et al. 1992) and in 


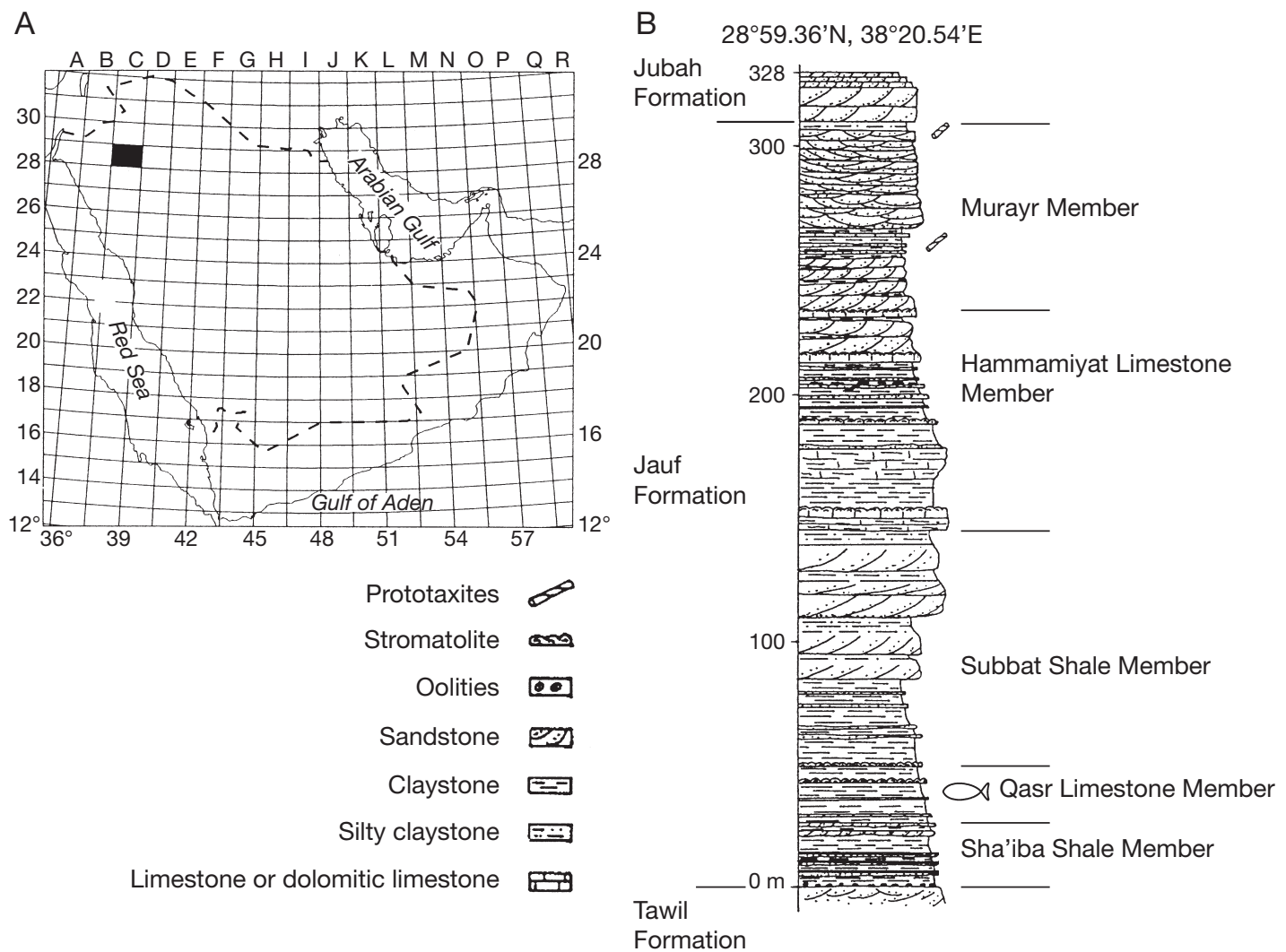

FIG. 1. - Geographical and geological settings the Qasr Limestone Member : A, Al Qalibah quadrangle; B, Al Huj section through the Jauf Formation; fish symbol represents the stratigraphical horizon where the material has been found (modified after Lelièvre et al. 1999).

three regions of northwest Saudi Arabia: Jauf, Ash Sha'iba and Al Huj. All three are within the Jauf Basin. In the Al Huj massif (Al Qalibah quadrangle), the Jauf Formation is subdivided into five members, Sha'iba, Qasr, Subbat, Hammamiyat, and Murayr (from oldest to youngest) primarily defined on lithologic characteristics (Lelièvre et al. 1994).

The Saudi acanthothoracid material comes from the Qasr Limestone Member (Fig. 1) dated as Praguian-Early Emsian on the basis of its vertebrate microremains assemblage (Lelièvre et al. 1994). The sedimentary matrix is a yellow clayey carbonate rock. Numerous skulls show an exceptional and rare three-dimensional preservation. All material has been mechanically prepared, in order to preserve the thin perichondral lamina coating the endocranial structures.
Specimens described, cited and figured in the text are deposited in the paleontology collection of the Muséum national d'Histoire naturelle, Paris (MNHN.F).

\section{ANATOMICAL ABBREVIATIONS}

Labels in italics indicate the sensory line system.

II optic nerve foramen;

III oculomotor nerve foramen;

III $\mathrm{p}$ foramen for oculomotor nerve posterior branch;

IV trochlear nerve foramen;

$\mathrm{V} \quad$ trigeminal nerve foramen;

V1 foramen for trigeminal nerve profundus branch;

$\mathrm{V}+\mathrm{VII}$ trigemino-facial duct;

VI abducens nerve canal and foramen;

VII hm foramen for hyomandibular branch of facial nerve;

VIII acoustic nerve canal;

IX glossopharyngeus nerve tract; 


\begin{tabular}{|c|c|}
\hline $\mathrm{X}$ & vagus nerve canal; \\
\hline $\mathrm{X}_{1}$ & foramen of the vagus nerve anterior branch; \\
\hline a.c.v & anterior cerebral vein; \\
\hline $\mathrm{Al}$ & anterior lateral plate; \\
\hline$c c$ & central sensory line groove; \\
\hline c.c & canal of endocranial extension of notochord; \\
\hline $\mathrm{Ce}$ & central plate; \\
\hline c.e & cranial cavity; \\
\hline cu.so & cutaneous sensory organ; \\
\hline c.v.ju & jugular vein canal; \\
\hline c.v.pit & pituitary vein canal; \\
\hline d.art & dermal articular area; \\
\hline d.end & endolymphatic duct opening; \\
\hline eys & eyestalk attachment area; \\
\hline fo.hy & hyoidean fossa; \\
\hline fo.pbr & peribranchial fossa; \\
\hline$i f c$ & infraorbital sensory line groove; \\
\hline lc & main lateral sensory line groove; \\
\hline $\mathrm{Mg}$ & marginal plate; \\
\hline m.o.fo & muscular occipital fossa; \\
\hline$m p l$ & middle pit line; \\
\hline my3 & $\begin{array}{l}\text { myodome for oculomotorius-innervated eye } \\
\text { muscle (superior rectus ?); }\end{array}$ \\
\hline my6 & $\begin{array}{l}\text { myodome for abducens-innervated eye mus- } \\
\text { cle; }\end{array}$ \\
\hline $\mathrm{Nu}$ & nuchal plate; \\
\hline occ & occipital cross comissure; \\
\hline orb & orbit; \\
\hline$p f c$ & profundus sensory line groove; \\
\hline $\mathrm{Pi}$ & pineal plate; \\
\hline$p m c$ & postmarginal sensory line canal; \\
\hline Pmg & postmarginal plate; \\
\hline Pn & paranuchal plate; \\
\hline Pan.a & anterior paranuchal plate; \\
\hline Pan.m & medial paranuchal plate; \\
\hline Pan.p & posterior paranuchal plate; \\
\hline ppl.a & posterior pit line anterior part; \\
\hline ppl.p & posterior pit line posterior part; \\
\hline pr.apo & anterior postorbital process; \\
\hline pr.gl & glenoid process; \\
\hline Prm & premedian plate; \\
\hline Pro & preorbital plate; \\
\hline pr.ppo & posterior postorbital process; \\
\hline pr.sv & supravagal process; \\
\hline $\mathrm{PtC}$ & posterior central plate; \\
\hline Ptn & postnasal plate; \\
\hline Pto & postorbital plate; \\
\hline Ro & rostral plate; \\
\hline $\mathrm{Rp}$ & rostropineal plate; \\
\hline $\mathrm{ru}$ & utricular recess; \\
\hline sac & sacculus; \\
\hline $\mathrm{Sm}$ & submarginal plate; \\
\hline $\begin{array}{l}\text { soc } \\
\text { v.hm }\end{array}$ & $\begin{array}{l}\text { supraorbital sensory line groove; } \\
\text { hyoid veins foramina. }\end{array}$ \\
\hline
\end{tabular}

\section{SYSTEMATICS}

Class PLACODERMI Mc Coy, 1848

\section{Order ACANTHOTHORACI Stensiö, 1944}

EMENDED DIAGNOSIS (modified from Denison 1978). The skull is moderately long and narrow with subparallel sides and a deep embayment on the posterior margin bounded by strongly projecting paranuchals. Dermal bones may be well developed and cover the cranial roof, or they may be separated or overlain by tesserae; two pairs of paranuchals are present. The orbits are lateral or dorso-lateral, and the nostrils are dorsal, bounded anteriorly by a premedian plate and surrounded postero-mesially by a small rostral plate. The suborbital plates are short and deep, without postorbital laminae. The lateral line sensory system occupies wide, open grooves or closed canals. An exoskeletal cranio-thoracic articulation is absent. The perichondraly ossified endocranium typically is moderately long and narrow with a rostrum projecting below and anterior to the rhinocapsular ossification. Dermal bones and scales are ornamented with tubercles that are commonly stellate.

\section{REMARKS}

Like all members of this order, Arabosteus n. gen. shows a typical sigmoid skull roof occipital border with a medial deep symmetric embayment and the posterior projection of the posterior paranuchal plate; large orbits oriented laterodorsally and a narrow interorbital wall are also special features present in most Acanthothoraci.

\section{Family Palaeacanthaspidae Stensiö, 1944}

DiAgNOSIs. - As for the order. To date this is the only family included in the order Acanthothoraci.

\section{Genus Arabosteus n. gen.}

TyPE SPECIES. - Arabosteus variabilis n. sp. by present designation.

ETymology. - In reference to its country of origin: Saudi Arabia.

Diagnosis. - As for type and only species. 

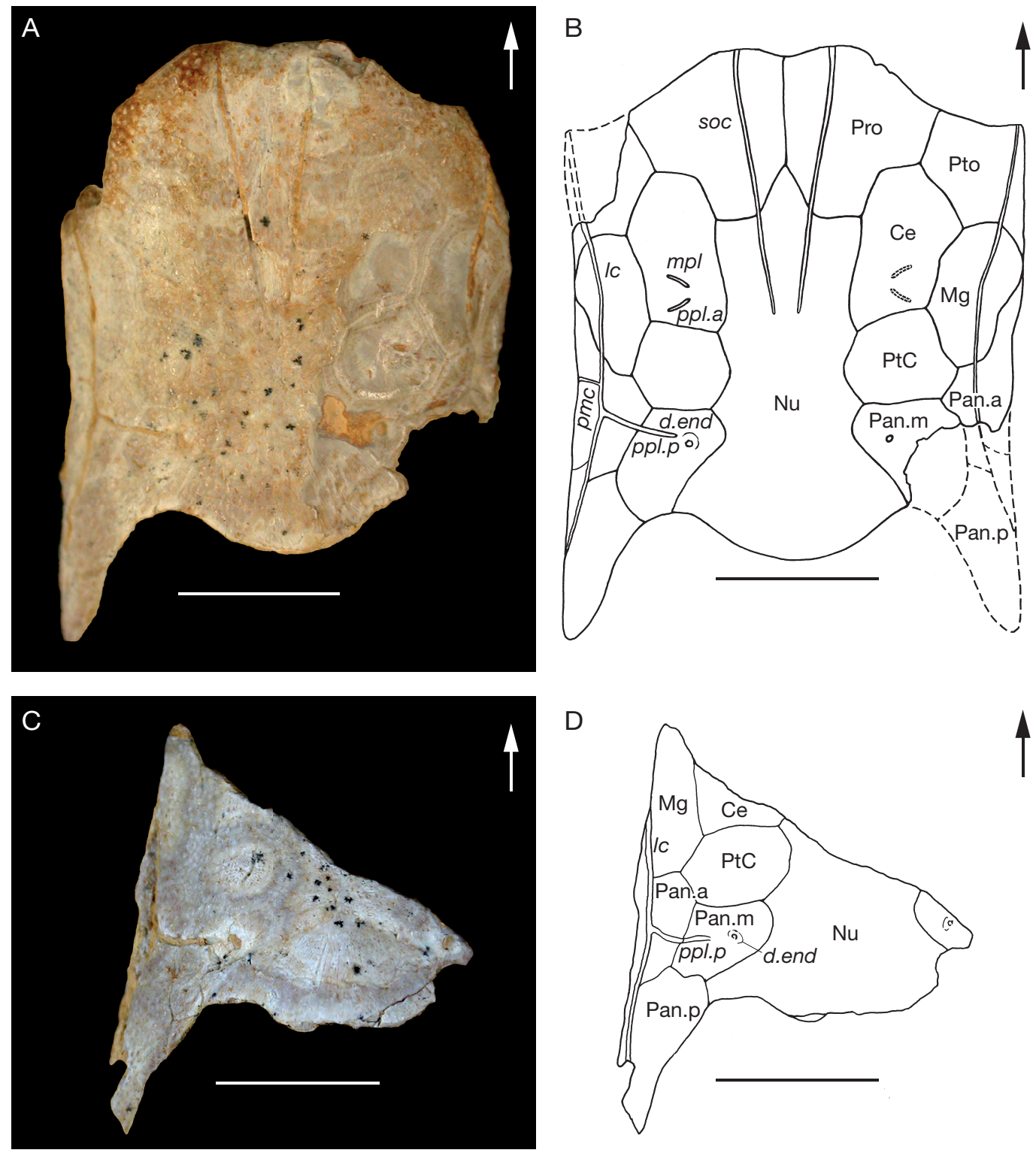

D

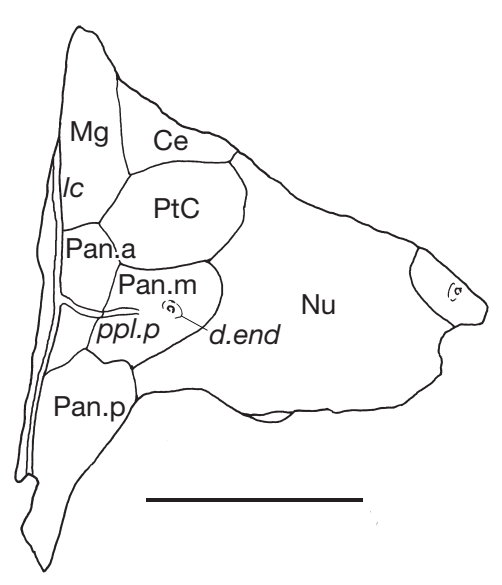

FIG. 2. - Incomplete skull roofs of Arabosteus variabilis n. gen., n. sp. in dorsal views: A, B, MNHN.F.1992-6-134, original specimen and skull roof reconstruction; C, D, MNHN.F.1992-6-135, original specimen and outline drawing of the bone suture pattern. Arrows indicate anterior. Labels in italics indicate the sensory line system; regular labels indicate the skull bones. Abbreviations: Ce, central plate; d.end, endolymphatic duct opening; $\mathbf{c}$, main lateral sensory line groove; $\mathbf{M g}$, marginal plate; $\mathbf{m p l}$, middle pit line; Nu, nuchal plate; Pan.a, anterior paranuchal plate; Pan.m, medial paranuchal plate; Pan.p, posterior paranuchal plate; pmc, postmarginal sensory line canal; ppl.a, posterior pit line anterior part; ppl.p, posterior pit line posterior part; Pro, preorbital plate; PtC, posterior central plate; Pto, postorbital plate; soc, supraorbital sensory line groove. Scale bars: $1 \mathrm{~cm}$. 


\section{Arabosteus variabilis $\mathrm{n} . \mathrm{sp}$.}

(Figs 2-8)

Acanthothoraci gen. and sp. indet. - Lelièvre et al. 1994: figs 2.8, 2.9; 1999: figs 4, 5 .

Holotype. - MNHN.F.1992-6-132 (Figs 3A, B; 5; 6).

Other material EXAMined. - Skull material: MNHN.F.1992-6-133 (Fig. 3C, D); 134 (Fig. 2A, B); 135 (Fig. 2C, D); 136 (Fig. 8); 137 (Fig. 4B); 138 (Fig. 4A); 139 (Figs 4C; 7).

Several other separate elements have been recognized among the material, namely two possible synarcual ossifications, and two partial post-branchial parts of the body armour (partial IL and AL plates). They may be assigned to the same taxon according to their characteristic ornamentation. In the same sample, numerous isolated scales with the same ornamentation, have been isolated by acid etching.

ETYMOLOGY. - variabilis in reference to the variable skull roof pattern present on this taxon.

Type locality. - Al Huj section, Al Qalibah area, Saudi Arabia.

TYPE HORIZON. — Qasr Limestone Member of the Jauf Formation.

DiAGNOSIS. - A small taxon of which the skull measures about $40 \mathrm{~mm}$ in length. Dermal skull roof covered with non-stellate elongate oval tubercles. Very long nuchal plate tapering to the front and meeting the preorbital plates. Supraorbital sensory line grooves extending posteriorly onto the nuchal plate. Presence of a supernumerary plate named posterior central, on several specimens, between the central and the medial paranuchal plates. Absence of the central sensory line.

\section{REMARKS}

All the characters of the previous diagnosis, except the size, distinguish Arabosteus variabilis n. gen., n. sp. from all other acanthothoracids.

In the Jauf Formation, another placoderm has been described: Nefudina qalibahensis Lelièvre, Janvier, Janjou \& Halawani, 1995. It is assigned to the rhenanids and differs considerably from A. variabilis n. gen., n. sp. by the size of the skull, the endocranium organization and its older stratigraphical position (Hammamiyat Member, Early Emsian).

\section{DESCRIPTION}

Skull roof

The studied material of Arabosteus variabilis n. gen., n. sp. includes eight partially preserved skulls with maximum length about $40 \mathrm{~mm}$ and maximum width about $30 \mathrm{~mm}$. Two specimens consist of an almost complete dermal skull roof (MNHN.F.1992-6-132 [Fig. 3A, B] and 134 [Fig. 2A, B]) and the six remaining ones (MNHN.F.1992-6-133 [Fig. 3C, D]; 135 [Fig. 2C, D]; 136 [Fig. 8]; 137 [Fig. 4B]; 138 [Fig. 4A]; 139 [Fig. 4C]) are fragments. The borders and limits of the Saudi Arabian skull roof plates are clearly exposed, in particular on specimens that have been partially eroded. Two suture patterns are observed. The first, type A (MNHN.F.1992-6-134 [Fig. 2A, B]; 135 [Fig. 2C, D]) shows two kinds of central plates (central plate [Ce] and posterior central plate $[\mathrm{PtC}])$; in the second, type $\mathrm{B}$, only one central plate (Ce) (MNHN.F.1992-6-132 [Fig. 3A, B]; 133 [Fig. 3C, D]; 137 [Fig. 4B]; 138 [Fig. 4A]).

The two different patterns could be interpreted as indicating different taxa. This hypothesis is not considered here because, given the information at hand, too many similarities exist in all the other anatomical skull features in the studied specimens. Therefore our best hypothesis is to consider all of them as belonging to a single species. The discovery of a specimen showing a mixed dissymmetrical pattern of the skull roof plates would be a proof against an interpretation of two different taxa.

The preorbital plates (Pro) are polygonal in shape, as wide as long and contact each other along the symmetry axis. They have the same size in both type A and type B skulls. Posteriorly they contact the nuchal plate along a sinusoidal suture. The supraorbital sensory line grooves (soc) pass right across the preorbitals, extending to the anterior third of the nuchal plate $(\mathrm{Nu})$. The elongate nuchal plate separating the paired central plates is longer than that of other described Acanthothoraci (e.g., Romundina stellina Orvig, 1975). This special feature also occurs in some arthrodires like Baringaspis dineleyi Miles, 1973 and Proaethaspis ohioensis Denison, 1960, but these forms lack the extension of the supraorbital sensory grooves onto the nuchal plate seen in A. variabilis n. gen., n. sp. 

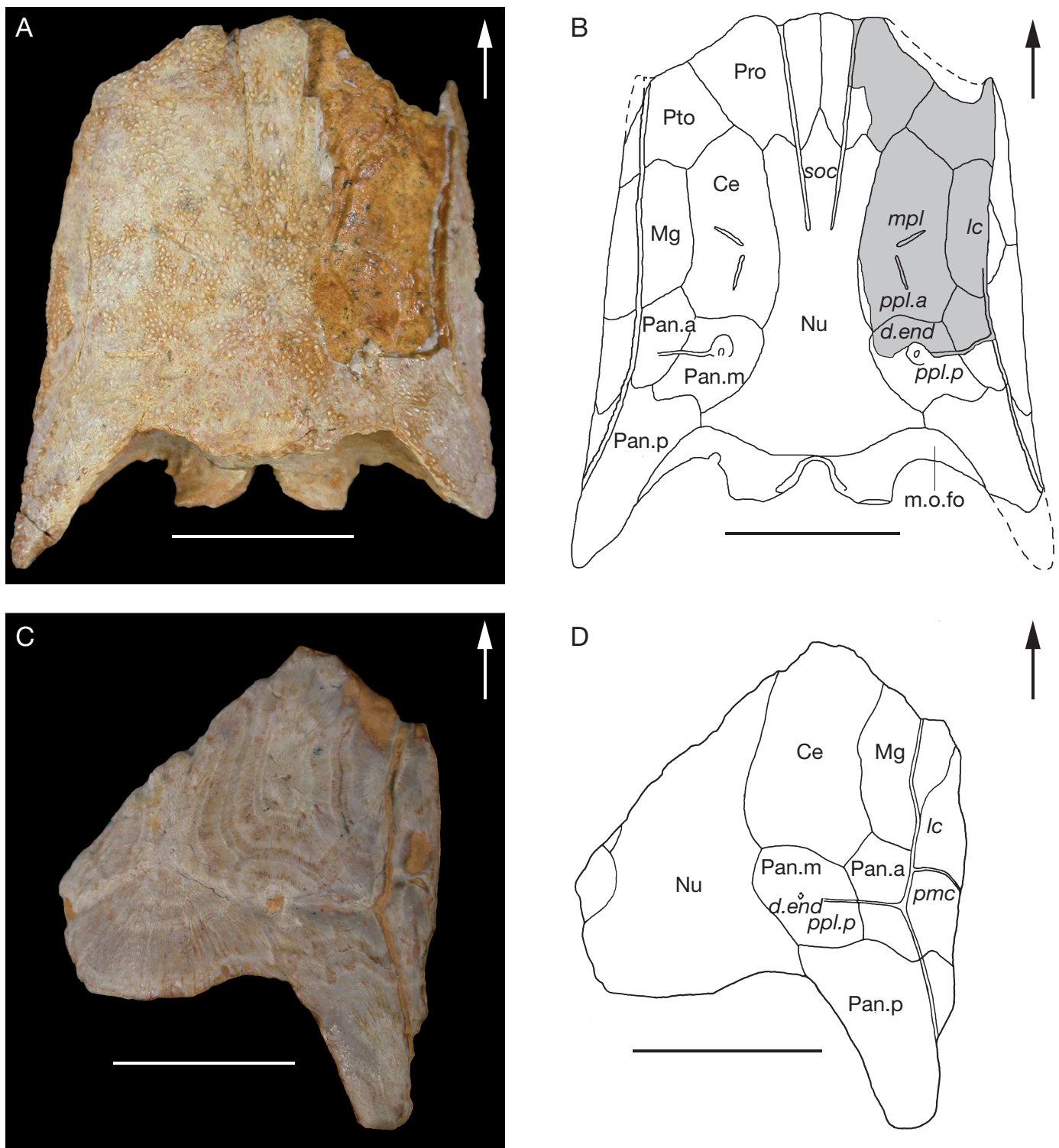

FIG. 3. - Incomplete skull roofs of Arabosteus variabilis n. gen., n. sp. in dorsal views: A, B, MNHN.F.1992-6-132, holotype and skull roof reconstruction; C, D, MNHN.F.1992-6-133, original specimen and outline drawing of the bone suture pattern. Arrows indicate anterior. The grey area indicates the missing external bone. Labels in italics indicate the sensory line system; regular labels indicate the skull bones. Abbreviations: $\mathbf{C e}$, central plate; $\boldsymbol{d}$.end, endolymphatic duct opening; $\mathbf{l c}$, main lateral sensory line groove; $\mathbf{M g}$, marginal plate, m.o.fo, muscular occipital fossa; $\mathbf{m p l}$, middle pit line; Nu, nuchal plate; Pan.a, anterior paranuchal plate; Pan.m, medial paranuchal

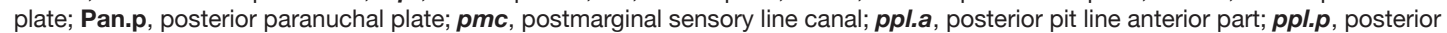
pit line posterior part; Pro, preorbital plate; Pto, postorbital plate; soc, supraorbital sensory line groove. Scale bars: $1 \mathrm{~cm}$.

The postorbital plates (Pto) are about half the size of the preorbital ones. The main lateral sensory line groove $(l c)$ crosses the plate to reach the lateral angle of the orbit. The main lateral sensory line groove is not distinguishable from the infra orbital canal since the central sensory line groove, which in most 
placoderm skulls marks the contact between both lines (Denison 1978: 33, fig. 22), is not present on any specimen of Arabosteus n. gen.

The central plates $(\mathrm{Ce})$ are quite elongate. The central plate of type B specimens covers, in length, almost half of the skull roof. In the type A, it covers only one third of it. Central plates are separated by an anterior extension of the nuchal plate. On the well-preserved external surface (specimens MNHN.F.1992-6-132 and 134; Figs 2A, B; 3A, $\mathrm{B})$, the central plates bear distinctly the middle pit line $(m p l)$ and the anterior part of the posterior pit line ( $p p l . a)$.

The endolymphatic duct (d.end) opens in a small pit at the radiation center of a separate plate that occupies the position of a medial paranuchal plate, as named here (Pan.m). The implications in reference to other groups of placoderms, where this plate has been given various names, will be discussed later. This plate also carries the posterior branch of the posterior pit-line ( $p$ l.p). On specimen MNHN.F.1992-6-134 (Fig. 2B), the medial paranuchal plate forms part of the posterior margin of the skull. On the other specimens (MNHN.F.1992-6-132, 133, 135; Figs 2D; 3B, D) the nuchal contacts the posterior paranuchal and excludes the medial paranuchal plate from the skull margin.

The anterior paranuchal plate (Pan.a) carries the confluence between the main lateral sensory line groove and the posterior part of the posterior pit line. Specimen MNHN.F.1992-6-132 (Fig. 3A, B) shows an interesting variation in the posterior pit line observation. The skull roof surface is not eroded on the left side and there is no visible external contact between this line and the main sensory line groove. The same region on the right side of specimen MNHN.F.1992-6-132 is broken. The break exposes this junction underneath the skull roof surface. A duct, within the bone, extends the posterior part of the posterior pit line to contact the main lateral line groove. Otherwise, on the lateral borders of the skull roof, some specimens present a postmarginal sensory line canal $(p m c)$ on the lateral part of the anterior paranuchal (MNHN.F.1992-6-133 and 134; Figs 2B; 3D). This canal has not been observed on the other specimens.
The posterior paranuchal plate (Pan.p) forms the postero-lateral border of the skull roof, and bears the posterior part of the main lateral sensory line groove. This plate also carries the articular joint with the body armour, observable on the internal side (d.art; Figs 5; 6).

A pair of posterior central plates $(\mathrm{PtC})$ characterizes the type A pattern. Those plates are located between the central plates and the medial paranuchal plates. The posterior central plates are hexagonal in shape and bear no grooves nor pit lines (Fig. 2B, D). Skull measurements indicate that these plates, when present, occupy space otherwise filled by a larger central plate. In fact, on specimen MNHN.F.1992-6-132, showing the type B pattern (Fig. 3A, B), the ratio "central plate length/skull medial length" is about 0.5 whereas on specimen MNHN.F.1992-6-134, showing the type A pattern (Fig. 2A, B) this ratio is about 0.3. In both specimens, the ratio "medial paranuchal plate length/ skull medial length" is approximately 0.25.

The marginal plate $(\mathrm{Mg})$ is found between the postorbital to the anterior, and the anterior paranuchal to the posterior. It has mesial contact with the posterior part of the central plate and the anterior part of the posterior central plate on those specimens with the latter plate (Fig. 2B, D). Otherwise it is in mesial contact with the central plate along its length (Fig. 3B, D). The shape of the marginal plate is variable and has a different role concerning the lateral margin of the skull roof. On specimen MNHN.F.1992-6-134 (Fig. 2B), it is almost excluded from the lateral margin of the skull whereas it is completely excluded on the right side of the specimen MNHN.F.1992-6-132 (Fig. 3B). For this specimen, the right lateral margin is therefore composed of the postorbital, anterior paranuchal and posterior paranuchal plate margins. The left lateral margin comprises one more plate with the presence of the marginal that occupies moreover a large part of it.

\section{The endocranium}

The endocranium has been partially preserved and prepared on four specimens: all (MNHN.F.1992-6-132, 137-139) show the orbital cavity on one or both sides (Fig. 7) and two (MNHN.F.1992-6-132, 


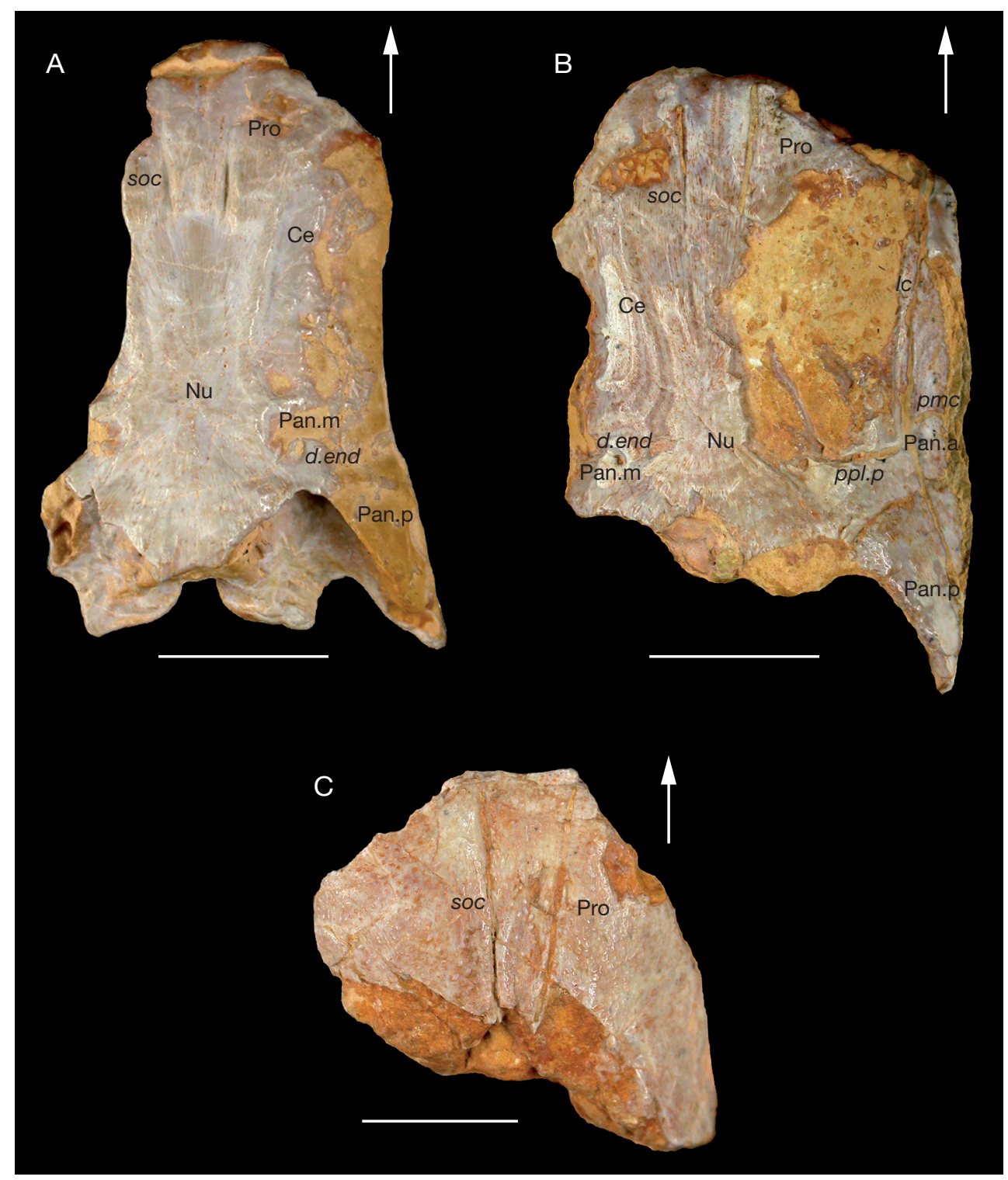

FIG. 4. - Incomplete skull roofs of Arabosteus variabilis n. gen., n. sp. in dorsal views: A, MNHN.F.1992-6-138; B, MNHN.F.1992-6-137; C, MNHN.F.1992-6-139. Arrows indicate anterior. Labels in italics indicate the sensory line system; regular labels indicate the skull bones. Abbreviations: $\mathrm{Ce}$, central plate; d.end, endolymphatic duct opening; Ic, main lateral sensory line groove; $\mathbf{N u}$, nuchal plate; pmc, postmarginal sensory line canal; Pan.a, anterior paranuchal plate; Pan.m, medial paranuchal plate; Pan.p, posterior paranuchal plate; ppl.p, posterior pit line posterior part; Pro, preorbital plate; soc, supraorbital sensory line groove. Scale bars: $1 \mathrm{~cm}$.

138) exhibit the occipital region (Fig. 6). One of them (MNHN.F.1992-6-132) has been more extensively prepared and shows an important part of the endocranium in ventral view (Fig. 5). The anterior part of the endocranium is never preserved in front of the optic nerve groove. A perichondral lining demonstrates the presence of the classic optic fissure observed in many placoderms and interpreted 

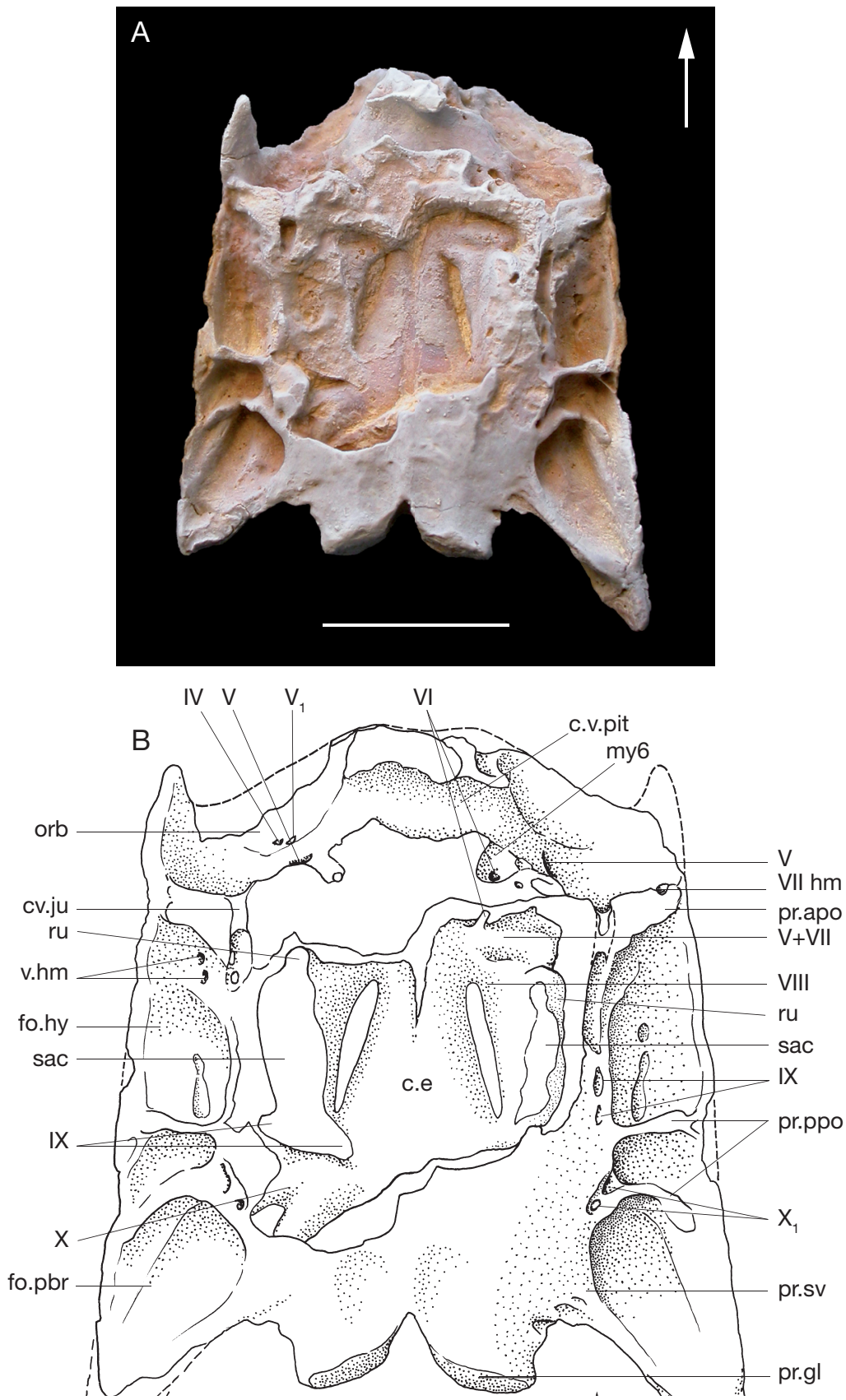

FIG. 5. - Endocranium of Arabosteus variabilis n. gen., n. sp. as preserved in the holotype (MNHN.F.1992-6-132): A, ventral view; $\mathbf{B}$, reconstruction. Arrows indicate anterior. Abbreviations: IV, trochlear nerve foramen; $\mathbf{V}$, trigeminal nerve foramen; $\mathbf{V}_{\mathbf{1}}$, foramen for trigeminal nerve profundus branch; V+VII, trigemino-facial duct; VI, abducens nerve canal and foramen; VII hm, foramen for hyomandibular branch of facial nerve; VIII, acoustic nerve canal; IX, glossopharyngeus nerve tract; $\mathbf{X}$, vagus nerve canal; $\mathbf{X}_{1}$, foramen of the vagus nerve anterior branch; c.e, cranial cavity; c.v.ju, jugular vein canal; c.v.pit, pituitary vein canal; d.art, dermal articular area; fo.hy, hyoidean fossa; fo.pbr, peribranchial fossa; my6, myodome for abducens-innervated eye muscle; orb, orbit; pr.apo, anterior postorbital process; pr.gl, glenoid process; pr.ppo, posterior postorbital process; pr.sv, supravagal process; ru, utricular recess; sac, sacculus; v.hm, hyoid veins foramina. Scale bars: $1 \mathrm{~cm}$. 
as a primitive feature among gnathostomes (Goujet $1984 a$, b; Young 1986). The ventral preorbital extension of the endocranium in other acanthothoracids supports the premedian plate. Neither this element of the dermal skull roof nor the rostral capsule has been recovered for Arabosteus variabilis n. gen., n. sp. Specimen MNHN.F.1992-6-132, with the most complete endocranial preservation, will serve as the basis for the present description (Fig. 5).

The specimen is ventrally incomplete with the ventral surface missing except in its most posterior part (Fig. 5), which shows the paired short glenoid condyles, on which a synarcual was presumably in contact with the articular surfaces (Fig. 6).

The endocranium (Fig. 5) is composed of a central body bearing paired lateral processes. These processes are disposed like in Romundina Orvig, 1975 and in "dolichothoracid" arthrodires (cf. Dicksonosteus Goujet, 1984 [Goujet 1984a: figs 4; 6] and Kujdanowiaspis Stensiö, 1942 cf. Stensiö 1963). From front to back, the anterior postorbital process (pr.apo) is relatively wide; on the anterior face, at the end of the left process, opens the canal for the hyomandibular branch of the facial nerve (VII hm), the same disposition as in actinolepid arthrodires (Stensiö 1969; Goujet 1984a) and other Acanthothoraci. On both sides, the processes have been eroded and the articular facet for the epihyal is not preserved.

The bifid posterolateral process (pr.ppo) is situated at the posterior third of the endocranium. Both branches are narrow and quite high, separated by a deep depression at the end of which opens a small foramen for the first branch of the vagus nerve $\left(\mathrm{X}_{1}\right)$. The main part of this nerve exits the endocranium in the peribranchial fossa (fo.pbr), which lies behind the posterior branch of the posterior postorbital process and in front of a narrow and elongate crest. This crest is assumed homologous to the supravagal process (pr.sv) of other groups of placoderms.

Dorsal to this crest is a deep depression, probably corresponding to a muscular cavity (m.o.fo, Figs 3B; 6). It profoundly hollows the occipital face of the skull on both sides of a blunt median ridge leading to a triangular opening that corresponds to the cerebral cavity (c.e) just above a round aperture of the endocranial notochordal cavity (c.c) (Fig. 6). The

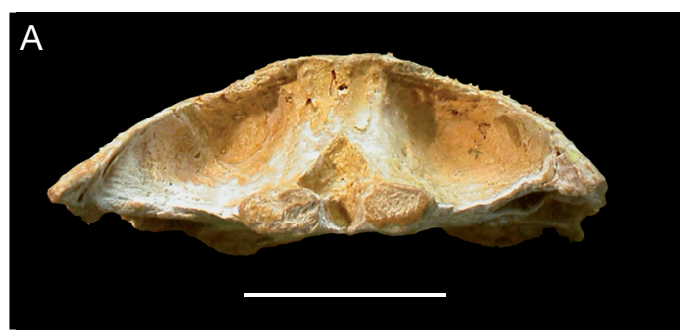

B

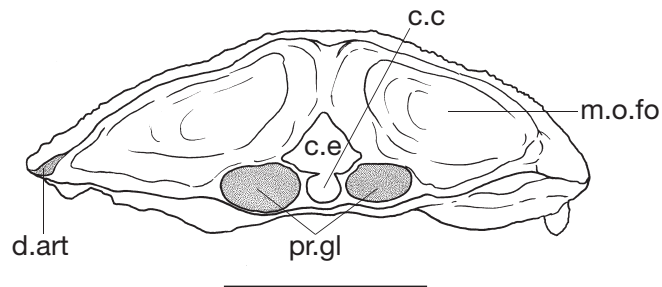

FIG. 6. - Arabosteus variabilis n. gen., n. sp. occipital area of the holotype (MNHN.F.1992-6-132): A, occipital view; B, interpretation. Abbreviations: c.c, canal of endocranial extension of notochord; c.e, cranial cavity (foramen magnum); d.art, dermal articular area; m.o.fo, muscular occipital fossa; pr.gl, glenoid process. Scale bars: $1 \mathrm{~cm}$.

occipital depressions may be homologous with the large cavities that are behind the supravagal process in petalichthyids (see Young 1978: fig. 4, where this cavity is called "cucullaris fossa").

The canal for the jugular vein (cv.ju) is partially preserved (Fig. 5) in the lateral part of the endocranium. Its path is more completely observable on the right hand side on the ventral view of specimen. It starts from the peribranchial chamber, at the root of the posterior branch of the posterior postorbital process. It is partially open behind the anterior postorbital process and crosses the process through a canal that opens in the posterior wall of the orbit. The exact extent of the groove is difficult to evaluate given the degree of ventral erosion of the endocranial body in its anterior half.

On the left side of the ventral view of specimen, two narrow and short lateral tubes (v.hm) starting from the jugular canal and opening on the lateral wall of the endocranium just behind the anterior postorbital process may represent tributaries for the hyoid arch drainage. Similar canals occur on the other side but are more difficult to represent. 

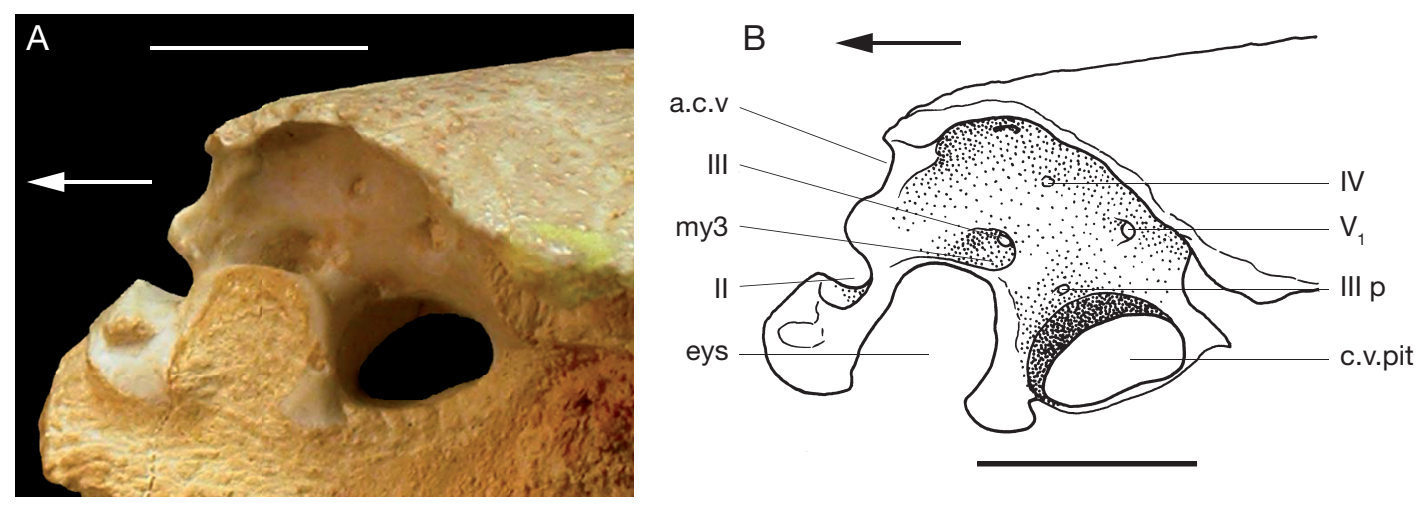

FIG. 7. - Left orbit of Arabosteus variabilis n. gen., n. sp. (MNHN.F.1992-6-139): A, lateral view; B, interpretation. Arrows indicate anterior. Abbreviations: II, groove for the optic nerve; III, oculomotor nerve foramen; III p, foramen for oculomotor nerve posterior branch; IV, trochlear nerve foramen; $\mathbf{V}_{\mathbf{1}}$, foramen for trigeminal nerve profundus branch; a.c.v, anterior cerebral vein; c.v.pit, pituitary vein canal; eys, eyestalk attachment area; my3, myodome for oculomotorius-innervated eye muscle (superior rectus?). Scale bars: $0.5 \mathrm{~cm}$.

Like in actinolepid and phlyctaeniid arthrodires (Goujet 1984a), the glossopharyngeus nerve canal (IX) opens just under the jugular canal closely in front of the root of the anterior branch of the posterior postorbital process. On specimen MNHN.F.1992-6-132, it opens with two foramina observable only on the left side of the ventral view.

The front part of the endocranium is very incomplete on specimen MNHN.F.1992-6-132 but it has been prepared in lateral view in two better-preserved specimens (MNHN.F.1992-6-138, 139; Fig. 7). In both lateral and ventral views, a striking feature is the large diameter of the pituitary vein canal (Fig. 7, c.v.pit) that connects both orbits behind a narrow prong corresponding to the interorbital wall, behind the optic nerve groove (Fig. 7B, II). In specimen MNHN.F.1992-6-132 (Fig. 5), given the ventral erosion of the endocranial body, it opens ventrally but in other specimens (MNHN.F.1992-6-138, 139; Fig. 7) it is still complete. Based on a difference with Romundina and arthrodires, where the canal remains relatively narrow, this large diameter could indicate that it may not be a passage for a simple vein but more likely a communication between two major orbital venous sinuses.

In front of this pituitary canal is the large oval eyestalk (Fig. 7, eys), which opens ventrally. This is the result of a lack in all specimens of perichondral lining observed under the entire orbital endocranial area. This absence may be due either to the preservation conditions or to mechanical weathering prior to fossilization.

The eyestalk is surrounded dorsally by the myodome (my3) in which opens the oculomotor nerve canal (III). A posterior branch (III p) opens through the eyestalk base, just at the margin of the pituitary canal (c.v.pit). In front of the eyestalk, the perichondral lining delimits dorsally the hind wall of the optic fissure and shows two clear embayments: ventrally for the optic nerve (II) and dorsally by the groove for the anterior cerebral vein (a.c.v). Such a pattern exists in the anterior end of the posterior endocranial ossification in all "loose nose" placoderms. In front was presumably a separate rostronasal ossification but this has not been recovered in our material.

Given this preservation in all our specimens, it is evident that, like Romundina and unlike $R a$ dotina Gross, 1950 and Kosoraspis Gross, 1959 (Gross 1959: fig. 1), a separate rostral capsule sat in front of the post-rostral ossification in A. variabilis n. gen., n. sp.

Partial preparation of the internal structures (Fig. 5) displays part of the encephalic cavity in the rhombencephalic region, and remains of both internal ear cavities with the canal for the acoustic nerve leading to them. The sacculus (sac) is very large relative to the space for the recessus utriculi 


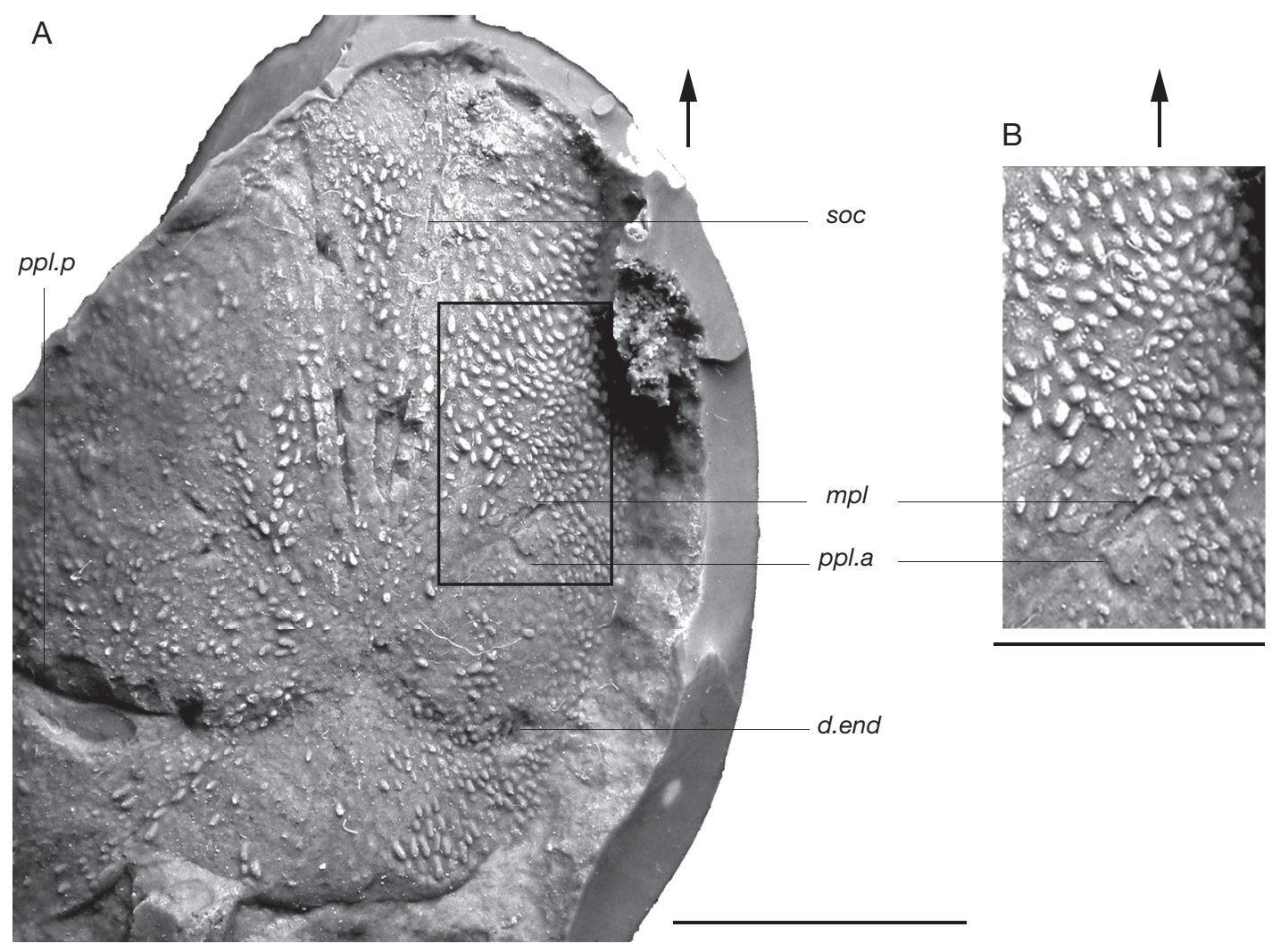

FIG. 8. - Arabosteus variabilis n. gen., n. sp. skull roof ornamentation (MNHN.F.1992-6-136): A, silicone cast of the skull roof impression in matrix; B, zoom showing oval and elongate tubercles. The black frame shows the enlarged area. Arrows indicate anterior. Labels in italics indicate the sensory line system. Abbreviations: $\boldsymbol{d}$.end, endolymphatic duct opening; $\boldsymbol{m} \boldsymbol{p l}$, middle pit line; ppl.a, posterior pit line anterior part; ppl.p, posterior pit line posterior part; soc, supraorbital sensory line groove. Scale bars: $A, 1 \mathrm{~cm} ; B, 0.5 \mathrm{~cm}$.

(ru). The semicircular canals have not been observed. The external (horizontal) canal should be located between the lateral endocranial wall and the sacculus. On the left side of the holotype, it was probably lost due to erosion. On the right side, it is not evident. The original endocranial wall has been intentionally preserved during the mechanical preparation in order to maintain some important anatomical features. Possibly the external semicircular canal was located more dorsally. A CT scan would be necessary to determine its position.

The base of the left labyrinth cavity on left side of the ventral view (Fig. 5) has been prepared, leaving the clear contour of the structure lined with perichondral bone. The posterior part shows two lobes continuous with the sacculus wall. These lobes may represent a section of the glossopharyngeus canal, which in many fish crosses at the bottom of the sacculus to exit laterally.

On the anterior right side of the ventral view (Fig. 5), the root of the trigemino-facial duct $(\mathrm{V}+\mathrm{VII})$ has been prepared; a narrow tube separated from this wide space to exit in the orbit in a small deep cavity, postero-ventrally to the pituitary vein canal, is observable. This tube corresponds to the passage of the abducens nerve (VI) and exits in a myodome (my6) most probably for the external rectus eye muscle (Goujet \& Young 2004; Young 2008).

\section{Dermal ornamentation}

Except on specimens MNHN.F.1992-6-133 and 135 that are superficially weathered, all the dermal 
skull roofs bear smooth oval and elongate tubercles (specimen MNHN.F.1992-6-136; Fig. 8) with variable sizes (from about 0.16 to $0.8 \mathrm{~mm}$ ). The tubercles are randomly distributed and do not follow the pattern of plates contrary to the condition in many other placoderms, e.g., Dicksonosteus (Goujet 1984a: pl. 2, fig. 2). This differs from other Acanthothoraci where stellate tubercles are present. However, a different ornamentation occurs also in Brindabellaspis Young, 1980 consisting of flattened roundish or angular tubercles (Young 1980: pl. 1; figs 1, 3, 4, 8). In Arabosteus n. gen., the ornamentation, even if it resembles Brindabellaspis is nevertheless clearly different; the tubercles are not flattened. We do not consider the gross resemblance in the ornamentation sufficient to assign it to the "Brindabellaspidae" Gardiner, 1993. The other anatomical features are close to the Palaeacanthaspidae and, at present, we provisionally assign Arabosteus variabilis n. gen., n. sp. to this family.

\section{DisCUSSION}

Arthrodira were among the first described representatives of placoderms (Agassiz 1833-1844; Pander 1857) and their skull roof organization was traditionally used as a reference regarding the dermal skull roof pattern in other groups of placoderms. Some problems arising from using arthrodiran plate terminology to apply to a group such as acanthothoracids are discussed below.

The first point of discussion concerns the paranuchal complex. Arthrodira have only one paranuchal plate (Fig. 9A) but Petalichthyida have two (posterior and anterior; Fig. 9B). The homology between these plates has been a source of debate (Westoll 1967). The single arthrodiran plate and the petalichthyid anterior plate are both characterized by the confluence between the main lateral sensory line groove and the posterior pit line also named posterior part of the posterior pit line by Goujet (1984a), as well as the presence of the endolymphatic pore (Goujet 1984b).

Definitions of paranuchal plates given by authors are relevant for Arthrodira but less useful for Acanthothoraci (Westoll 1967; Denison 1978). Denison's (1978) interpretation of paranuchal plates as the plates crossed by the main lateral sensory line groove and by the posterior part of the posterior pit line is relevant for Arthrodira, which have only one paranuchal but ambiguous for instance for Acanthothoraci, which present a different paranuchal complex.

In published Acanthothoraci specimens, one pair of anterior and one pair of posterior paranuchal plates are present, when identified (Denison 1978: fig. 22). The endolymphatic pore opens, in some Acanthothoraci like Romundina stellina on a separate plate. This plate was interpreted as a medial paranuchal plate by Orvig (1975) and Goujet \& Young (2004) (Fig. 9C) and as a second central (Ce2) by Denison (1978).

Arabosteus variabilis $\mathrm{n}$. gen., n. sp. presents a similar paranuchal plate pattern to Romundina stellina. The posterior paranuchal plate is only crossed by the main lateral sensory line groove like in Romundina stellina and Lunaspis broilii Gross, 1937. The name "posterior paranuchal" is then kept for the same plate in the Saudi taxon. Therefore, the posterior paranuchal would be characterized by the presence of the main sensory line groove, by its posterior marginal position and its articular joint with the body armor. In A. variabilis n. gen., n. sp., the plate anterior to the posterior paranuchal plate bears the confluence of the main lateral sensory line groove and the posterior pit line. This plate does not enclose the endolymphatic duct opening. Contrary to Arthrodira and Petalichthyida, there is not a single plate bearing the confluence and the duct opening, but each occurs on different plates: an anterior paranuchal characterized by the groove confluence and a medial paranuchal plate by the endolymphatic foramen and adjoining the paranuchals. This is also the case in Romundina stellina. The medial paranuchal plate could be named "endolymphatic plate" in order to highlight its characteristics and this terminology could be used as well in other acanthothoracids for the homologous structure (e.g., R. stellina; Fig. 9C). The position of the endolymphatic pore is very variable. For example in Antiarchi or Petalichthyida (Denison 1978) it can be very close to the median line and in Arthrodira postero-lateral near the cephalic-lateral line, between the posterior pit-line posterior part and the occipital line (Stensiö 1963; Goujet 1984b). Therefore, we 

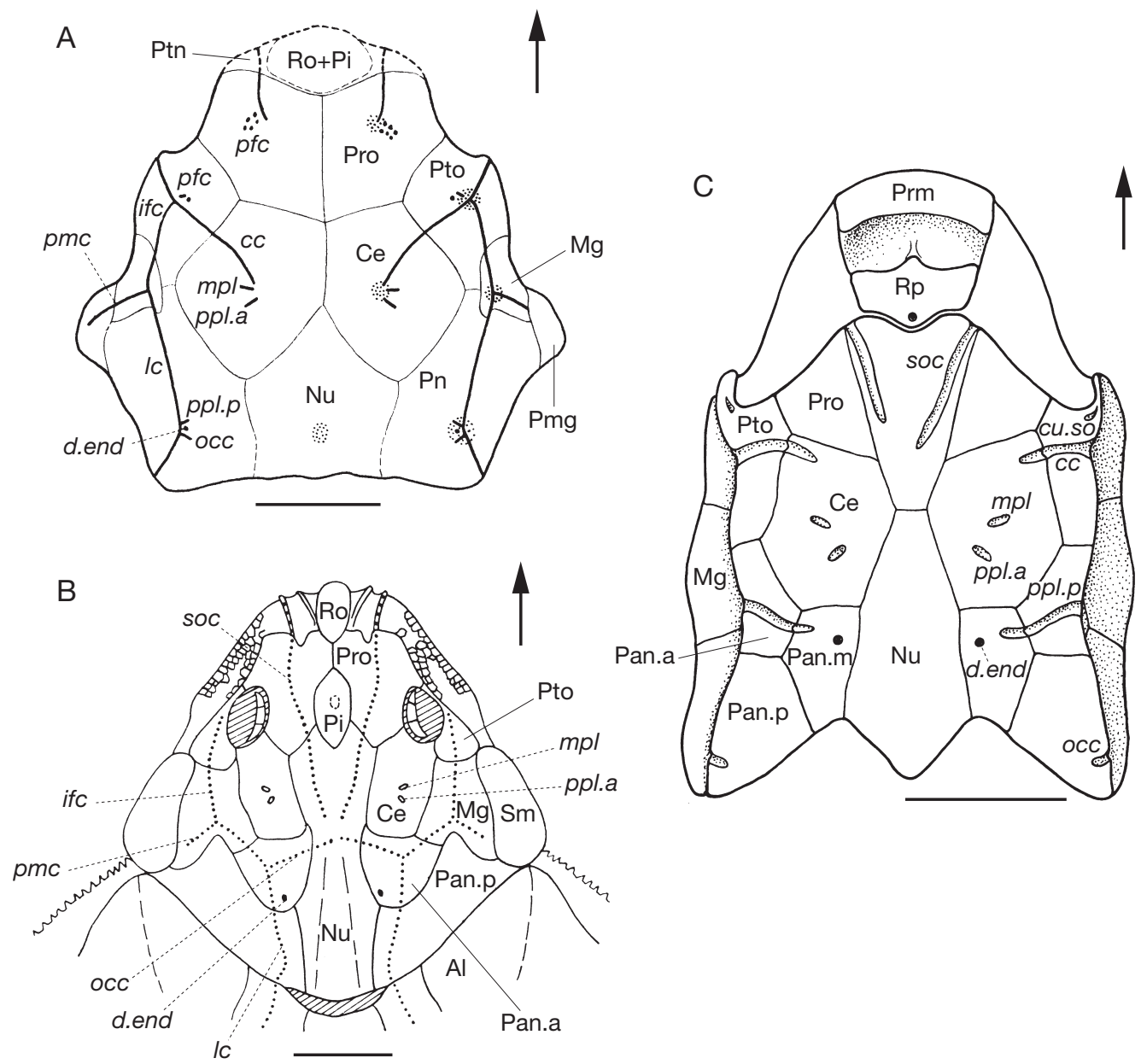

FIG. 9. - Reconstructions of the skull roof of: A, the arthrodire Simblaspis cachensis Denison, 1958 (modified after Denison 1958); B, the petalichthyid Lunaspis broilii Gross, 1937 (modified after Goujet 1972); C, the acanthothoracid Romundina stellina Orvig, 1975 (modified after Goujet \& Young 2004). Arrows indicate anterior. Labels in italics indicate the sensory line system; regular labels indicate the skull bones. Abbreviations: Al, anterior lateral plate; $\boldsymbol{c c}$, central sensory line groove; Ce, central plate; cu.so, cutaneous sensory organ; d.end, endolymphatic duct opening; ifc, infraorbital sensory line groove; Ic, main lateral sensory line groove; Mg, marginal plate; mpl, middle pit line; Nu, nuchal plate; occ, occipital cross commissure; Pan.a, anterior paranuchal plate; Pan.m, medial paranuchal plate; Pan.p, posterior paranuchal plate; $\mathbf{p f c}$, profundus sensory line groove; Pi, pineal plate; pmc, postmarginal sensory line groove; Pmg, postmarginal plate; Pn, paranuchal plate; ppl.a, posterior pit line anterior part; ppl.p, posterior pit line posterior part; Prm, premedian plate; Pro, preorbital plate; Ptn, postnasal plate; Pto, postorbital plate; Ro, rostral plate; Rp, rostropineal plate; Sm, submarginal plate; soc, supraorbital sensory line groove. Scale bars: A, $1 \mathrm{~cm} ; \mathrm{B}, 2 \mathrm{~cm} ; \mathrm{C}, 0.5 \mathrm{~cm}$.

prefer to keep the traditional plate nomenclature, generally connected with a strict positional situation of the different plates. Denison's (1978) interpretation of this plate, as a second central, has less justification than as a medial paranuchal plate because the plate appears as a component of the paranuchal complex. Based on this interpretation, the hypotheses of fusion-fragmentation of dermal skull roof components in various placoderm groups can be discussed.

Regarding the paranuchal complex, two different processes can be invoked to interpret the pattern existing in other placoderm groups. An assumption of bone fusion process would imply 
that acanthothoracids are a "primitive" condition with the arthrodiran paranuchal formed by fusion of the three plates identified in $A$. variabilis n. gen., n. sp. If bone fragmentation is the model, then the anterior, posterior and medial paranuchal plates of Arabosteus n. gen. would be interpreted as derived and the single arthrodiran paranuchal as primitive.

In both cases, the pattern in Petalichthyida would be an intermediate condition.

A second remark concerns the anterior paranuchal plate versus the marginal plate. Traditionally, the marginal plate is defined in arthrodires as the skull component bearing the main lateral sensory line groove and the postmarginal sensory line groove (Goujet 1984a: 102).

On some specimens of Arabosteus variabilis n. gen., n. sp. (specimens MNHN.F.1992-6-133 and 134; Figs $2 \mathrm{~A}, \mathrm{~B} ; 3 \mathrm{C}, \mathrm{D})$, the postmarginal sensory line groove is observable on the marginal part of the plate previously identified as an anterior paranuchal plate. Thus, that plate could also be named the marginal plate. It can be noted that the post-marginal sensory line groove of $A$. variabilis n. gen., n. sp. is inserted into the bone. Therefore, it should be better called "post-marginal canal", even if it sometimes opens along a continuous slit.

This canal is not observable or present on that plate in some other Saudi specimens (MNHN.F.1992-6-132 and135; Figs 2C, D; 3A, B). Thus, the identification as a "marginal plate" is not obvious. Additionally, it contacts medially the medial paranuchal plate and the posterior paranuchal plate posteriorly. Therefore it belongs to the paranuchal complex and may also correspond to the anterior paranuchal plate. It also bears the confluence between the main sensory line groove and the posterior part of the posterior pit line, a characteristic for a paranuchal plate.

Thus, the lateral line system on its own is ambiguous for deciding bone homology and terminology (Graham-Smith 1978). This plate could be either called marginal plate or anterior paranuchal plate depending on the chosen reference system.

In the present work, we use the term "anterior paranuchal". This interpretation is based on 1) the position of the confluence between the main sensory line groove and the posterior part of the posterior pit line, which seems to be a constant characteristic among placoderms, and 2) the position of the plate as part of the paranuchal complex. Therefore, the presence of the postmarginal canal is not used to characterize the marginal plate. This feature is used in arthrodires, but does not seem presently relevant for the establishment of homologies in acanthothoracids given its instability.

\section{Acknowledgements}

The authors would like to thank the reviewers Martin Rücklin (University of Bristol) and Gavin Young (Australian National University) for their fruitful comments and particularly GY for the improvement given to the English text. The authors are also grateful to Laura Wilson (University of Colorado) for her proofreading of the manuscript. Thanks to the Ministry of Petroleum and Mineral Resources Deputy Ministry for Mineral Resources Jeddah of the Saudi Arabia Kingdom and the Bureau des Ressources géologiques et minières, Jeddah, Saudi Arabia, for the organization of the field trip to Saudi Arabia in 1992.

\section{REFERENCES}

Agassiz J. L. R. 1833-1844. - Recherches sur les poissons fossiles. 5 volumes et atlas. Imprimerie Petitpierre, Neuchâtel.

Burrow C. J., Lelièvre H. \& Janjou D. 2006. — Gnathostome microremains from the Lower Devonian Jawf Formation, Saudi Arabia. Journal of Paleontology 80: 537-560.

DENISON R. H. 1958. — Early Devonian fishes from Utah. Part III. Arthrodira. Fieldiana: Geology 11: 461-551.

Denison R. H. 1978. - Placodermi, in Schultze H. P. (ed.), Handbook of Paleoichthyology. Volume 2. Gustav Fischer, Stuttgart, 128 p.

Forey P. L., Young V. T. \& MC Clure H. 1992. Lower Devonian fishes from Saudi Arabia. Bulletin of the British Museum (Natural History), Geology series 48: 25-42.

GOUjET D. 1972. - Nouvelles observations sur la joue d'Arctolepis (Eastman) et d'autres Dolichothoraci. Annales de paléontologie (Vertébrés) 58: 1-14.

GoujeT D. 1984a. - Les poissons Placodermes du Spitsberg: Arthrodires Dolichothoraci de la formation de WoodBay (Dévonien inférieur). Cahiers de paléontologie. CNRS, Paris, 284 p. 
GoujeT D. 1984b. — Placoderm interrelationships: a new interpretation, with a short review of placoderm classifications. Proceedings of the Linnean Society of New South Wales 107: 211-243.

Goujet D. \& Young G. C. 1995. — Interrelationships of placoderms revisited. Geobios, Mémoire Spécial 19: 89-95.

GOUjET D. \& Young G. C. 2004. — Placoderm anatomy and phylogeny: new insights, in ARRATIA G., WILSON M. V. \& Cloutier R. (eds), Recent Advances in the Origin and Early Radiation of Vertebrates. Verlag Dr Friedrich Pfeil, München: 109-126.

GRAHAM-SMITH W. 1978. - On some variations in the latero-sensory lines of the placoderm fish Bothriolepis. Philosophical Transactions of the Royal Society of London Series B, Biological Sciences 282: 1-39.

Gross W. 1958. — Uber die älteste Arthrodiren Gattung. Notizblatt des Hessischen Landesamtes fur Bodenforschung, Wiesbaden 86: 7-30.

Gross W. 1959. - Arthrodiren aus dem Obersilur der Prager Mulde. Palaeontographica A 113: 1-35.

Lelièvre H., Janjou D., Halawani M., Janvier P., AlMuallem M. S., Wynns R. \& Robelin C. 1994. Nouveaux vertébrés (Placodermes, Acanthodiens, Chondrichthyens et Sarcoptérygiens) de la Formation de Jauf (Dévonien inférieur, région de $\mathrm{Al} \mathrm{Huj}$, Arabie Saoudite). Comptes rendus de l'Académie des Sciences de Paris (série II) 319: 1247-1254.

Lelièvre H., Janvier P., Janjou D. \& Halawani M. 1995. - Nefudina qalibahensis nov. gen., nov. sp. un rhénanide (Vertebrata Placodermi) du Dévonien inférieur de la Formation Jauf (Emsien) d'Arabie Saoudite. Geobios, Mémoire Spécial 19: 109-115.

Lelièvre H., Al-Muallem M. S., Goujet D., Halawani M., Janjou D., Janvier P. \& Robelin C. 1999. — Early Devonian Vertebrates from the Jauf Formation Saudi Arabia. Saudi Arabian Deputy Ministry for Mineral Resources Technical Report BRGM-TR-13-5, 26 p.

Mark-KuriK E. 1973. - Kimaspis, a new Palaeacan- thaspid from the early Devonian of Central Asia. Eesti NSV Teaduste Akadeemia Toimetised 22: 322-330.

OrVIG T. 1975. - Description, with special reference to the dermal skeleton, of a new radotinid arthrodire from the Gedinnian of Arctic Canada. Colloque international, CNRS 218: 41-71.

Pander C. H. 1857. - Über die Placodermen des devonischen Systems. Kaiserliche Akademie des Wissenschaften, Sankt Petersburg, 106 p.

SMiTH R. E. 1980. — Lower Devonian (Lochkovian) biostratigraphy and brachiopod faunas of the $\mathrm{Ca}$ nadian arctic islands. Geological Survey of Canada Bulletin 308: 1-155.

STENSIÖ E. A. 1942. - On the snout of Arthrodires. Kungliga Svenska VetenskapsAkademiens Handlingar 20: 1-32.

STENSIÖ E. A. 1963. - Anatomical studies on the Arthrodiran head. Kungliga Svenska Vetenskapsakademiens Handlingar 9: 1-149.

STENSIÖ E. A. 1969. - Elasmobranchiomorpha, Placodermata, Arthrodires, in Piveteau J. (ed.), Traité de Paléontologie IV. Volume 2. Masson, Paris: 71-692.

Westoll T. S. 1967. - Radotina and other tesserate fishes. Journal of the Linnean Society (Zoology) 47: 83-98.

YounG G. C. 1978. - A new Early Devonian petalichthyid fish from the Taemas/Wee Jasper region of New South Wales. Alcheringa 2: 103-116.

YounG G. C. 1980. - A new Early Devonian placoderm from New South Wales, Australia, with a discussion of placoderm phylogeny. Palaeontographica A 167: 10-76.

YounG G. C. 1986. - The relationships of placoderm fishes. Journal of the Linnean Society (Zoology) 88: $1-57$.

YounG G. C. 2008. - Number and arrangement of extraocular muscles in primitive gnathostomes: evidence from extinct placoderm fishes. Biology letters 4: $110-114$. 